\title{
Vegetational changes during the last millennium inferred from a palynological record from the Bananal Island, Tocantins, Brazil
}

\author{
Laís Aguiar da Silveira MENDES ${ }^{*}$, Etiene Fabbrin PIRES ${ }^{1}$, Maria Ecilene Nunes da Silva MENESES², \\ Hermann BEHLING ${ }^{3}$ \\ 1 Universidade Federal do Tocantins, Laboratório de Paleobiologia, Curso de Ciências Biológicas, Campus de Porto Nacional, Jardim dos Ipês, s/n, 77500-000 Porto Nacional, T0, Brasil; \\ 2 Universidade Federal do Tocantins, Laboratório de Solos, Curso de Geografia, Campus de Porto Nacional, Jardim dos Ipês, s/n, 77500-000 Porto Nacional, T0, Brasil; \\ ${ }^{3}$ University of Göttingen, Department of Palynology and Climate Dynamics, Albrecht-von-Haller-Institute for Plant Sciences, Untere Karspüle 2, 37073 Göttingen, Germany; \\ *Corresponding author: laisasmendes@gmail.com
}

\section{ABSTRACT}

The Bananal Island is regarded the largest fluvial island in the world, bounded by Araguaia and Javaés rivers, being located in southwest of Tocantins. The objectives of this work were to provide information about the vegetational changes that occurred at the Bananal Island, in order to contribute to the understanding the dynamics of past and current savanna and areas of ecotones with forests. Thus, a sedimentary core collected from a small lake at the Bananal Island plain was submitted to pollen and radiocarbon dating analyses. The results showed that the last millennium was dominated by forest reflecting a wet climate. At the beginning of the record (920-770 yr cal BP) the wet climate and high rainfall produced flooding during long rainy seasons that maintained the Javaés River connected to the studied lake, and hence, this environment was marked by the presence of a homogenous forest rich in Moraceae/Urticaceae, due to flooded soils occurrence. During the following period (770-304 yr cal BP) the reduced rainfall and shortening of the rainy seasons isolated the lake from the Javaés River for long periods, which caused a diversification of the forest and gave rise to the appearance of the components of floodplain forest and marsh vegetation adapted to waterlogged soils. Since 304 years cal BP to the present day this environment remained dominated by this diverse forest and the lacustrine conditions were also similar to previous phase, with a slight increase of moisture in the last 84 years that caused the increase of Piranhea.

KEYWORDS: Floodplain, Late Holocene, Palynology.

\section{Mudanças na vegetação durante o ultimo milênio inferidas através do registro palinológico da Ilha do Bananal, Tocantins, Brasil}

\section{RESUMO}

A Ilha do Bananal é considerada a maior ilha fluvial do mundo, margeada pelos Rios Araguaia e Javaés, sendo localizada na porção sudoeste do Estado do Tocantins. Os objetivos deste trabalho foram obter informaçôes sobre as mudanças na vegetação ocorridas na Ilha do Bananal, de forma a contribuir para o entendimento da dinâmica pretérita e atual da vegetaçáo de cerrado e áreas de ecótonos com floresta. Assim, um testemunho sedimentar coletado em um pequeno lago na planície da Ilha do Bananal foi submetido às análises polínica e de datação por radiocarbono. Os resultados mostraram que o ultimo milênio foi dominado por floresta refletindo um clima úmido. No início do registro (920-770 anos cal AP) o clima úmido e a alta pluviosidade produziram inundaçóes durante longos períodos chuvosos que mantiveram o rio Javaés conectado ao lago estudado, e assim, este ambiente foi marcado pela presença de uma floresta homogênea rica em Moraceae/Urticaceae, devido à ocorrência de solos alagados. Durante o período seguinte (770-304 anos cal AP) a pluviosidade reduzida e o encurtamento dos períodos chuvosos isolaram o lago do rio Javaés por longos períodos, que causou a diversificação da floresta e deram origem ao aparecimento de componentes da vegetação de floresta de planície de inundaçáo e brejos adaptados a solos úmidos. Desde 304 anos cal AP até o presente este ambiente tem sido dominado por esta floresta diversificada e as condiçôes lacustres também foram similares ao período anterior, com um ligeiro aumento de umidade nos últimos 84 anos o que causou o aumento de Piranhea.

PALAVRAS-CHAVE: Holoceno Tardio, Palinologia, planície de inundação. 


\section{INTRODUCTION}

The Bananal Basin is a well-developed Quaternary sedimentary basin, located in the region of the middle Araguaia River with approximately 106,000 km² (Figure 1). According to Valente (2007) the Bananal Basin is the most important intracratonic sedimentary basin of the Quaternary from South America and preserves a good record of paleohydrological conditions.

In northern portion of this sedimentary basin, in the Tocantins State, occurs the Bananal Island with an area of $20,000 \mathrm{~km}^{2}$. It is considered the largest fluvial island in the world (Borma et al. 2009; Dias et al. 2011; Devi 2012). The island is a floodplain temporarily flooded during the rainy season by precipitation of local waters, being classified as a seasonal wetland (Valente 2007). According to Brasil (1981) the island morfological unit is characterized by a fluvial-lacustrine plain, with numerous lakes, lagoons and intermittent channels. The topography of this region is flat with few isolated residual hills (Mileski 1994).

The Bananal Island is protected by Araguaia National Park created in December $31^{\text {th }} 1959$, by decree No 47,570 of the Federal Government, including the whole island (Brasil 1981). The boundary of Araguaia National Park is located in north of Bananal Island, comprising part of municipalities of Pium (north) and Lagoa da Confusão (south) covering an area of 5,623.12 $\mathrm{km}^{2}$, according to the last change decree on 84.844 from 1980 .

Despite the importance of Bananal Island, considered one of the last natural refuges of fauna and flora towards Cerrado region (Valente et al. 2013), it has been poorly studied and still no paper about past vegetation history was conducted within the Araguaia National Park, even the data about the modern vegetation like floristic inventory are rare. There is only one record using pollen analysis in the region near to the island, carried out by Behling (2002). The author analyzed sediments collected in the Lagoa da Confusão, a small lake located in the homonymous city (about $145 \mathrm{~km}$ far from the Bananal 8), whose record allowed recognizing the changes in vegetation occurred during the late Pleistocene and Holocene. This study is also the only one for the Tocantins State, a region whose vegetation is so diverse and consists mainly of savanna and palm swamp so-called "veredas" (typical cerrado vegetation formations). This region also harbors rainforests and palm forests ("babaçuais"). The paleoenvironmental and paleoclimatic history of this region is poorly known, being necessary to search information about the plant formations changes possibly occurred in this region during the Late Pleistocene and Holocene.

On the other hand, the dynamics of climate and vegetation of the Cerrado have been relatively well studied in other states such as Minas Gerais, Goiás and Distrito Federal, especially for the Holocene period (Ferraz-Vicentini and Salgado-Labouriau 1996; Salgado-Labouriau et al. 1997; Barberi et al. 2000). In all of these records were observed a trend in increased humidity during the Late Holocene with a climate similar to the present.

In the Amazon region the vegetational changes occurred in the Pleistocene and especially in the Holocene, have been investigated both in forested regions (Colinvaux et al. 1996; Bush et al. 2004; Irion et al. 2006) as well as in the regions of savannas (Absy et al. 1991; Hermanowski et al. 2012; Meneses et al. 2013).

The objectives of this work were to investigate the accumulated sediments in the Bananal Island (TO) floodplain in order to obtain information about vegetational changes during the Late Holocene in this region. Thus, this paper intended to analyze the dynamics of the local and regional vegetation, inferring about the environmental, as well as human impacts that possibly occurred during this period, and thereby contributing to studies that seek to understand the dynamics of past and current savanna and areas of ecotones with forests.

\section{MATERIALS AND METHODS}

\section{Description of the study area}

This study was carried out in the county of Pium, Tocantins State, in Bananal Island within the limits of the Araguaia National Park (Figure 1). The climate is humid with little or not water deficit (B2rA' a') (SEPLAN/TO 2008). The average annual temperature for the region is approximately $24^{\circ} \mathrm{C}$ and elevation about $180 \mathrm{~m}$. The mean annual precipitation is about $2,000 \mathrm{~mm}$, being characterized by a seasonal distribution of rainfall that defines a dry season (May to September) and a rainy season (October to April).

Regarding the vegetation of the Bananal Island, Eiten (1985) emphasizes that there is a predominance of a transition area between the Cerrado and Amazon Forest Biomes. Therefore, the area can be considered an ecotone sensu Odum (1976). In this context, a couple of authors (Nunes et al. 2012; Rossetti et al. 2012) described the Amazon Forest Biome with some phytophysiognomies, but these are often forest formations. On the other hand, the Cerrado Biome is characterized by Ribeiro and Walter (2008) with some phytophysiognomies, that are classified generally as cerrado stricto sensu (that include savanna formations such as dense, typical and thin cerrado) and cerrado lato sensu (that include forest formations). Hence, the Cerrado Biome is characterized by a very complex vegetational formations that show a variation of physiognomy and floristic composition, with about $1,5 \%$ of endemic plants, regarded as one of the 25 Earth hotspots for biodiversity conservation (Mittermeier et al. 1998; Myers et al. 2000). At the Bananal Island both biomes (Amazon Forest and Cerrado Biomes) occur, being the Cerrado stricto sensu. 


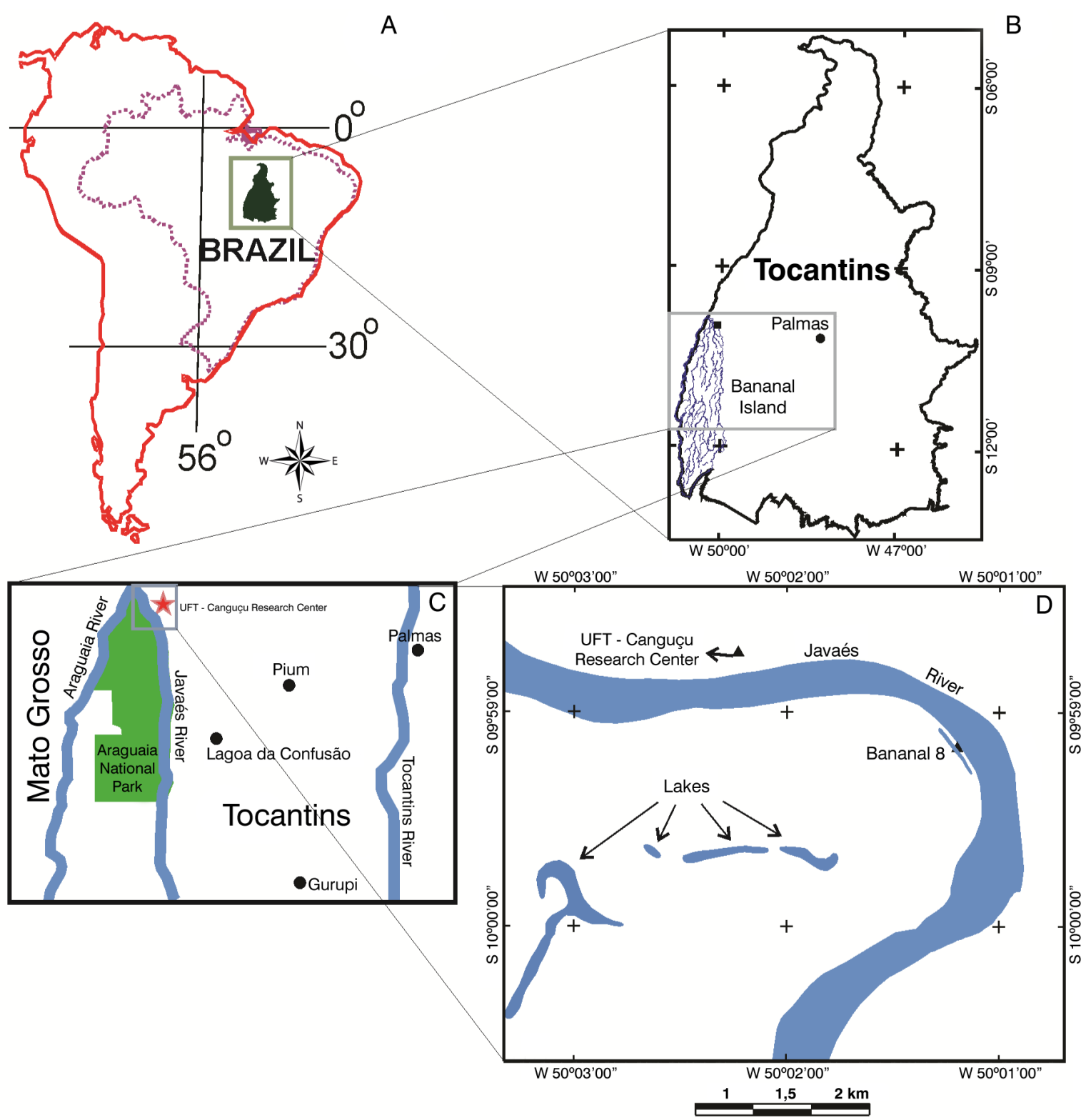

Figure 1. Geographic location of the study area. A. Geographic location of the Tocantins State. B. Tocantins map showing the Bananal Island. C. Detail of the Araguaia National Park, indicating the Canguçu Research Center. D. Detail of the collection site Bananal 8.

According to SEPLAN/TO (2008), the soils of this region are classified as being alluvial deposits of recent age (holocenic), with sandy sedimentation active in the formation of lower levels, also appearing gleysol soil type in the natural fragments of flooded forests, and plinthosols in the rest of the region. These soils are shallow and are under strong influence of groundwater.

\section{Sampling and methods}

In order to obtain the access to study area, it was necessary previously an authorization document of the Brazilian
Institute of Environment and Renewable Natural Resources of Tocantins (IBAMA-TO), through of the Authorization and Information System on Biodiversity (SISBIO) - authorization for activities with scientific purpose, number 30453-1.

The coring site consists of a lake about $900 \mathrm{~m}$ in circumference, located about $120 \mathrm{~m}$ from the right edge of Bananal Island (S 09 $59^{\prime} 09.8^{\prime \prime}$ and W 050 01'12.1') (Figure 1 ), near to the Javaés river, part of the geomorphological is unit classified as floodplain (Valente et al. 2013). The sediment core was taken using a "Russian Trade". The sampled core 
was stored in a PVC pipe (channel) covered by plastic film in order to avoid contamination. The core collected was named Bananal 8, it has $100 \mathrm{~cm}$ and it was open for analysis at the Paleobiology's Laboratory, Porto Nacional Campus, from Universidade Federal do Tocantins (UFT).

Sub-samples of $1 \mathrm{~cm}^{3}$ were taken every $5 \mathrm{~cm}$ totaling 21 sub-samples. The chemical treatment of sub-samples for pollen analysis followed the procedures for palynological extraction of pollen grains adopted by Faegri and Iversen (1989) as well as including acetolysis method described by Erdtman (1952). The procedures for pollen preparation included the addition of exotic Lycopodium clavatum $\mathrm{L}$. spores to determine pollen concentration (grains $\mathrm{cm}^{-3}$ ) and accumulation rates (grains $\mathrm{cm}^{-2}$ year $^{-1}$ ).

The pollen grains, spores and other palynomorphs were identified by optical microscopy (L1000T, Bioval, Jiangbei, China), using the objective of $40 \mathrm{x}$, and with 100x when grains that could not be identified with a smaller magnifications. The computer program Neotropical pollen (free to use) was used, and pollen keys of Carreira and Barth (2003), Colinvaux et al. (2005), Salgado-Labouriau (1973), Rivas (1978) and Roubik and Moreno (1991) were used to identify pollen grains. A minimum of 300 pollen grains were counted for each sub-sample.

The identified pollen grains were grouped by ecological affinities according to habitat, such as forest, floodplain forest, marsh, savanna (Cerrado stricto sensu) and palm trees to facilitate plotting data, and the sum of pollen groups, floodplain forest and marsh were united for better understanding of data, because both of them are indicative of wet conditions. To calculate and plot the pollen diagram TILIA and TILIAGRAPH softwares were used (Grimm 1987), programs with licensed use. Within this program was performed a cluster analysis (CONISS).

Two sediment subsamples of $3 \mathrm{~cm}$ in thickness were taken from the core and dated by the "Accelerator Mass Spectrometry" (AMS), from the base $(100 \mathrm{~cm})$ and from the middle $(50 \mathrm{~cm})$, in the Beta Analytic Radiocarbon Dating Laboratory (Miami, Florida, USA). The ${ }^{14} \mathrm{C}$ ages obtained were calibrated in years before present (BP) through the software CALIB 6.0 (Stuiver and Reimer 1993).

\section{RESULTS}

\section{Lithology and radiocarbon dating}

The Bananal 8 core was $100 \mathrm{~cm}$ thick. Its constitution from the base to $81 \mathrm{~cm}$ was represented by sediment characterized as brown fine sandy. Between $81 \mathrm{~cm}$ and the top $(0 \mathrm{~cm}$ the upper surface) the sediment comprised a gray sandy clay, being rich in leaves and roots from $20 \mathrm{~cm}$ to the top (Figure 2, 3 and 4).

Ages obtained by ${ }^{14} \mathrm{C}$ analysis indicated that the studied core deposition occurred entirely during the Late Holocene. The dating from the base revealed to be $920 \pm 30$ years calibrated (cal) BP and the sample at $50 \mathrm{~cm}$ was dated in 670 \pm 30 years calibrated BP. Samples obtained and calibrated ages from Bananal 8 core are shown in Table 1.

Table 1. Radiocarbon dating and calibrated (cal) ages. BP - Before present. yr - years.

\begin{tabular}{ccccc}
\hline Depth & $\begin{array}{c}\text { Laboratory } \\
\text { number }\end{array}$ & 13C/12C (\%) & $\begin{array}{c}\text { Convencional } \\
\text { Age 14C - BP }\end{array}$ & $\begin{array}{c}\text { Calibrated age } \\
\text { (cal yr BP) }\end{array}$ \\
\hline 50 & Beta -315473 & -26.8 & $670 \pm 30$ & 760 \\
100 & Beta -315474 & -25.1 & $900 \pm 30$ & 920 \\
\hline
\end{tabular}

\section{Description of pollen record diagram}

A total of 87 taxa of palynomorphs were identified (Table 2) along to the Bananal 8 core, including taxa of algae, bryophytes, pteridophytes and angiosperms. The concentration of carbonized particles was not enough for to be included in the analysis. The pollen diagram (Figure 2 and 3) shows the distribution of palynomorphs which were grouped according to their ecological affinities (habitat) and the sum of environmental groups is shown in Figure 3. The cluster analysis (CONISS) discriminate analyses the major paleofloristics changes occurring in pollen groups. It was possible to establish three distinct ecological phases, BAN I, BAN II and BAN III, which are described below (BAN is the abbreviation for Bananal, name of the island where the core was taken), in an ascending stratigraphic order.

Phase BAN I $(100$ to $68 \mathrm{~cm}: 920 \pm 30$ to $770 \pm 30$ years cal BP, 7 subsamples). This phase was characterized by the abundance of forest components (68-86\%), which are dominated by Moraceae/Urticaceae (43-73\%), Alchornea (1-13\%) Cecropia (2-11\%), Melastomataceae/Combretaceae (0.3-5\%), Myrtaceae (0-4\%), Malpighiaceae (0-2\%), Fabaceae (Papilonoideae) (0-2\%), Baubinia type 2 (0-1\%), Asteraceae (0-1\%), Fabaceae (Caesalpinioideae) (0-1\%), Celtis (0-1\%), and other taxa are less than $1 \%$. The savanna ecological group consists mainly of Poaceae, Mimosa, Cyperaceae, Byrsonima and Borreria presented pollen summing between 11 and 29\%. The ecological group marsh showed percentages between 0 and $2 \%$. Ecological groups of palms and floodplain forest computed percentages less than $1 \%$ each. Algae amounted 0.6 to $2 \%$, bryophytes and pteridophytes spores added $0-3 \%$.

Phase BAN II (68 to $22 \mathrm{~cm}: 770 \pm 30$ to $304 \pm 30$ years cal BP, 9 subsamples). Ecological groups remained in the same proportion, forest (64-80\%), occurring a small increase of the most representative taxa. Moraceae/Urticaceae remained the most representative type (8-45\%), but now followed by Cecropia (5-29\%), Alchornea (4-26\%), Sapium (0.3-10\%), Myrtaceae (3-8\%), Melastomataceae/Combretaceae (1-8\%), Fabaceae (Caesalpinioideae) (0-7\%), Piper (0-4\%), Euphorbiaceae 


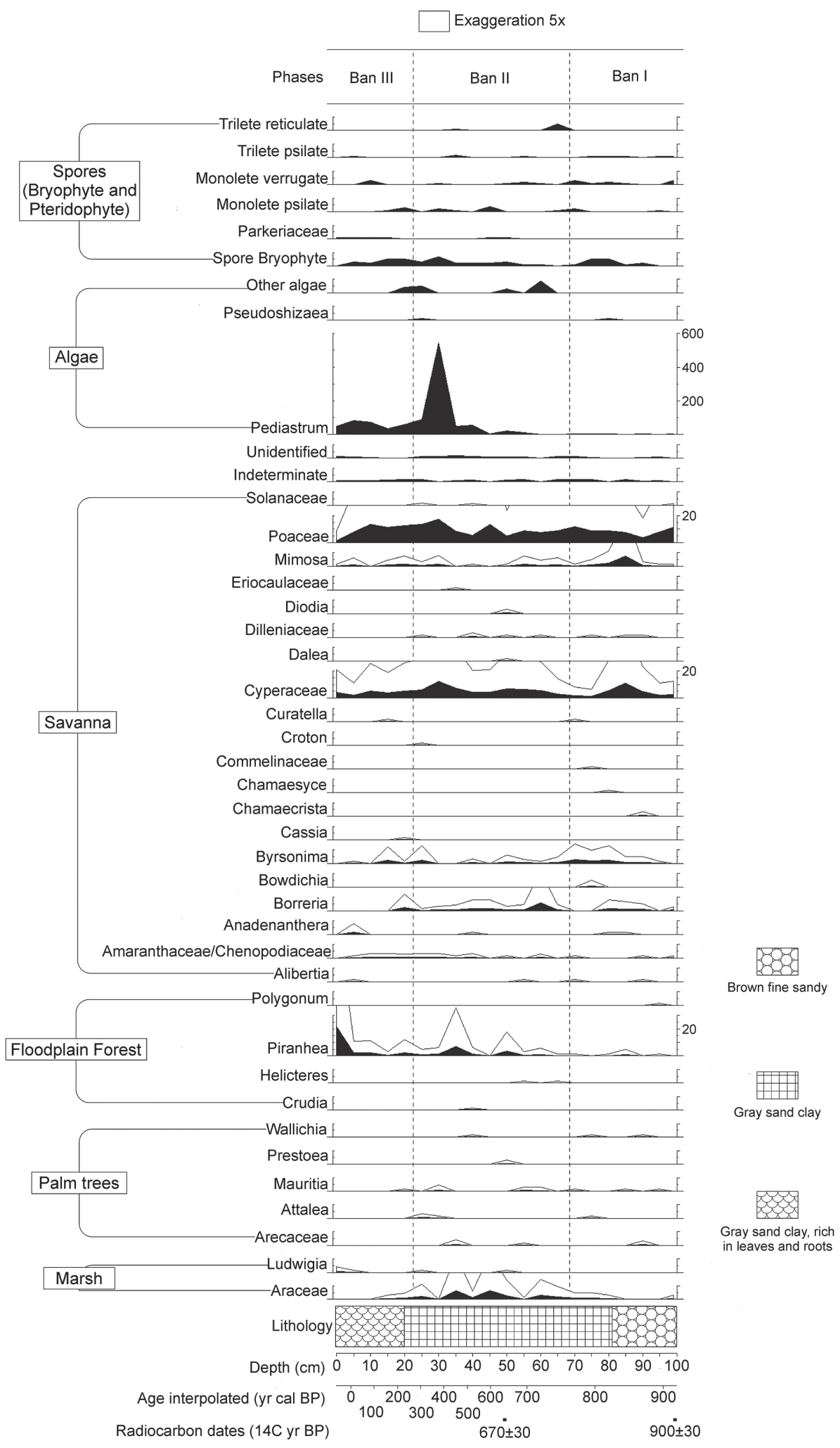

Figure 2. Pollen diagram percentages of Bananal 8 core with taxa included in ecological groups such as marsh, palm trees, floodplain forest, savanna, algae, spores (Bryophytes and Pteridophytes). It features a $5 x$ exaggeration to better visualization of pollen types with low percentages. 


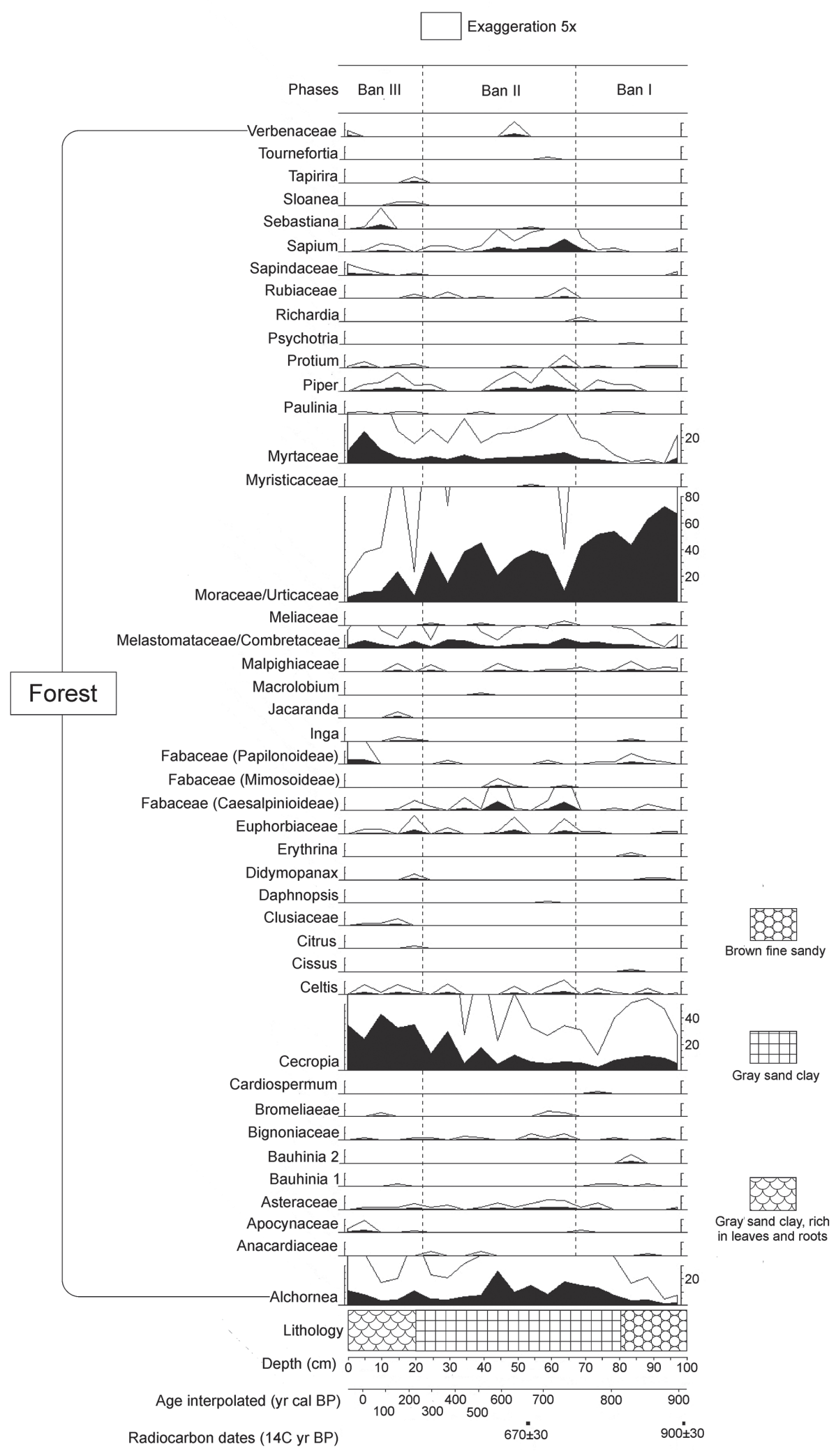

Figure 3. Pollen diagram percentages of Bananal 8 core with taxa included in ecological group Forest. It features a $5 x$ exaggeration to better visualization of pollen types with low percentages. 


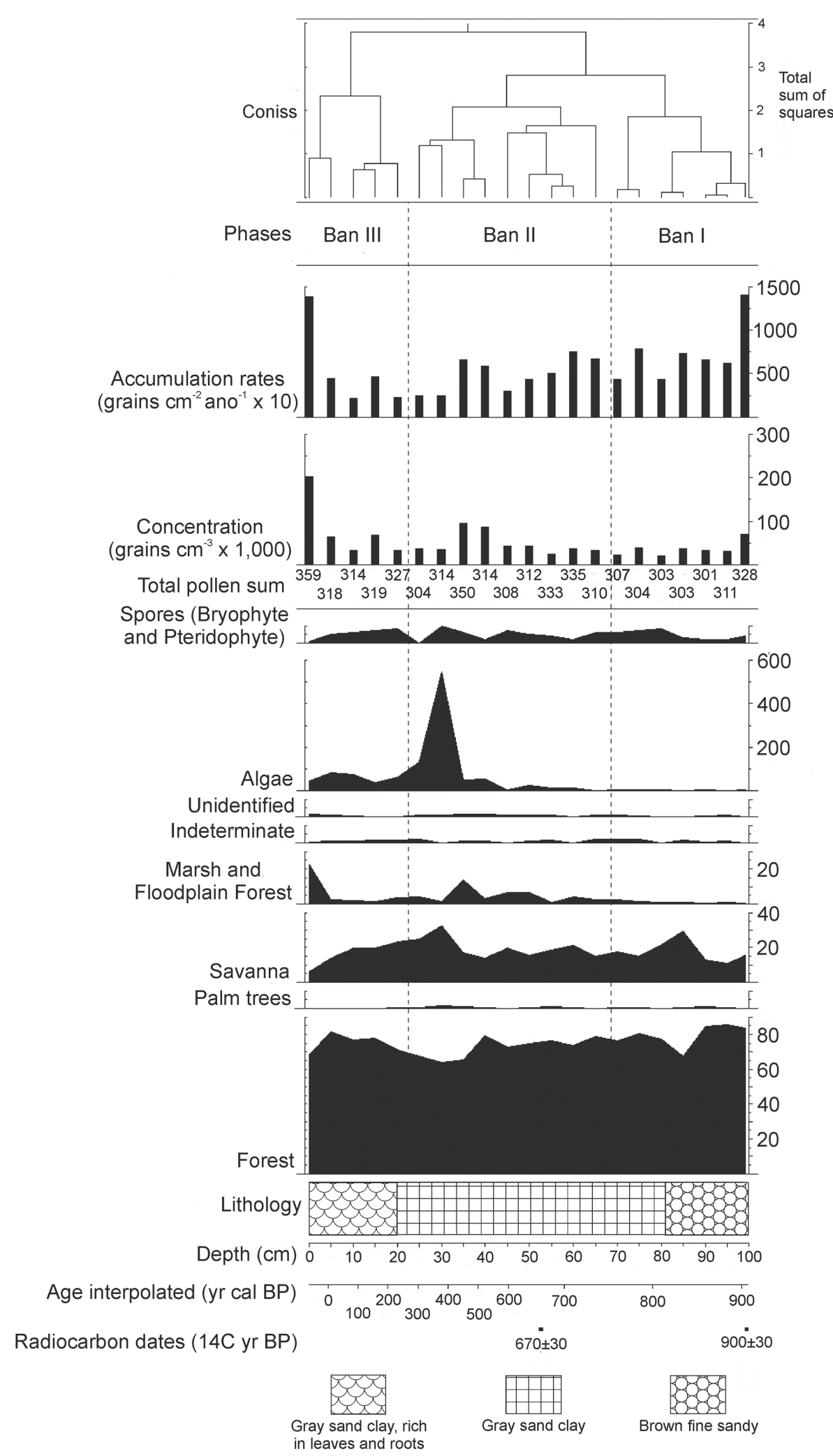

Figure 4. Summary pollen diagram showing radiocarbon ages, interpolated ages, lithology, ecological groups, pollen sum, pollen concentration and accumulation rate, pollen phases and cluster analysis (CONISS). 
Table 2. List of pollen taxa found in this paper incorporated the ecological groups: algae, marsh, spores, floodplain forest, palm trees, savanna and forest.

\begin{tabular}{|c|c|}
\hline ALGAE & SAVANNA (Continuation) \\
\hline Other algae & Mimosa \\
\hline Pediastrum & Poaceae \\
\hline Pseudoschizaea & Solanaceae \\
\hline MARSH & FOREST \\
\hline Alismataceae & Alchornea \\
\hline Araceae & Anacardiaceae \\
\hline Convovulaceae & Apocynaceae \\
\hline Cuphea & Asteraceae \\
\hline Lenthibulariaceae & Bauhinia 1 \\
\hline Ludwigia & Bauhinia 2 \\
\hline SPORES & Bignoniaceae \\
\hline Bryophyta spore & Bromeliaceae \\
\hline Monolete psilate & Cardiospermum \\
\hline Monolete verrucate & Cecropia \\
\hline Parkeriaceae & Celtis \\
\hline Trilete psilate & Cissus \\
\hline Trilete reticulate & Citrus \\
\hline FLOODPLAIN FOREST & Clusiaceae \\
\hline Crudia & Daphnopsis \\
\hline Helicteres & Didimopanax \\
\hline Piranhea & Erythrina \\
\hline Polygonum & Fabaceae (Caesalpinioideae) \\
\hline PALM TREES & Fabaceae (Mimosoideae) \\
\hline Arecaceae & Fabaceae (Papilonoideae) \\
\hline Attalea & Inga \\
\hline Mauritia & Jacaranda \\
\hline Prestoea & Macrolobium \\
\hline Wallichia & Malpighiaceae \\
\hline SAVANNA & Melastomataceae/Combretaceae \\
\hline Alibertia & Meliaceae \\
\hline Amaranthaceae/Chenopodiaceae & Moraceae/Urticaceae \\
\hline Anathenanthera & Myristicaceae \\
\hline Borreria & Myrtaceae \\
\hline Bowdichia & Paullinia \\
\hline Byrsonima & Piper \\
\hline CassiaChamaecrista & Protium \\
\hline Chamaesyce & Psycotria \\
\hline Commelinaceae & Richardia \\
\hline Croton & Rubiaceae \\
\hline Curatella & Sapindaceae \\
\hline Cyperaceae & Sapium \\
\hline Dalea & Sloanea \\
\hline Dilleniaceae & Tapirira \\
\hline Diodia & Tournefortia \\
\hline Eriocaulaceae & Verbenaceae \\
\hline
\end{tabular}

(0-3\%), Celtis (0-2\%) Verbenaceae (0-2\%), Protium (0-2\%), Rubiaceae (0-2\%), Asteraceae (0-2\%), Fabaceae (Mimosoideae) $(0-1 \%)$, Malpighiaceae $(0-1 \%)$, and other taxa are less than $1 \%$. The savanna ecological group, consisting mainly of the same types already described (Poaceae, Mimosa, Cyperaceae, Byrsonima and Borreria), presented at this phase its largest representation, the pollen percentages summing between 14 and $33 \%$. Ecological groups of marsh and floodplain forest, together, showed percentages between 0 and 14\%. Palm trees made $0-1 \%$. But this phase was marked by a sharp increase of algae, represented almost exclusively by Pediastrum (0-177\%) relative to the total pollen sum. Bryophytes and pteridophytes spores remain underrepresented (0-7\%).

Phase BAN III (22 to $0 \mathrm{~cm}: 304 \pm 30$ years cal BP to the present, 5 subsamples). In this phase there was an increase in the representation of ecological groups dependent of water. Taxa of forest had alternating representation, where Cecropia (24-43\%) had the highest percentage, followed by Myrtaceae (3-24\%), Moraceae/Urticaceae (4-23\%), Alchornea (4-11\%), Melastomataceae/Combretaceae (2-6\%), Fabaceae (Papilonoideae) (0-4\%), Piper and Euphorbiaceae (0-3\%), Apocynaceae (0-2\%), Sapindaceae (0-2\%), Celtis (0-2\%), Fabaceae (Caesalpinioideae) (0-2\%), Sapium and Malpighiaceae $(0-1 \%)$, and other taxa are less than $1 \%$. Savanna ecological group presented its smaller representation, pollen sum between 6-23\%. Floodplain forest and marsh vegetation amounted 0.6$23 \%$, being exclusively represented by Piranhea. Palm trees kept low percentage $(0-0.3 \%)$. Bryophytes and pteridophytes spores amounted to $0-4 \%$ and the algae had a sharp decline (11-27\%) compared to the previous phase.

\section{DISCUSSION}

\section{The dynamics of vegetation during the last millennium}

The results obtained from the pollen analysis of the Bananal 8 core revealed few changes in the vegetational composition during the last millennium in the Bananal Island.

During the period of 920-770 years cal BP (Phase BAN I) predominated taxa from forest, mainly represented by Moraceae/Urticaceae. The abundance of pollen types of these families can be explained by the fact that some genus have an anemophilous pollination syndrome (Martins and Batalha 2006), like for example Brosimum described by Santos and Lolis (2007) in the current regional vegetation. On the other hand, the dominance of this single family can be indicative of an environment permanently flooded, avoiding the colonization by other family representative, once these extreme conditions are unfavorable for the most of the species. It is possible that the rainy season had extended duration and the events of floods kept the Javaés River connected to studied 
lake (fluviatile conditions) for a long period of time due to high annual precipitation.

The taxa of savanna were poorly represented if compared to forest. However, a peak is observed at about 845 years cal BP, mainly Cyperaceae, possibly due to colonization of the lake margin. The other vegetation formations were underrepresented. Bryophytes and pteridophytes were rare, keeping this small proportion throughout the entire core. This fact can be explained by the hygrophilous habit of bryophytes and pteridophytes (Raven et al. 2007). Thus, because of the studied local is flooded, such conditions may not be favorable for these groups.

Between 770 and 304 years cal BP (Phase BAN II) the forest taxa remained abundant. However, in addition to the abundant presence of Moraceae/Urticaceae, other types occurred with higher percentages (Cecropia, Alchornea, Sapium, Myrtaceae, Melastomataceae/Combretaceae, Fabaceae (Caesalpinioideae), Piper, Euphorbiaceae, Celtis, Verbenaceae, Protium, Rubiaceae, Asteraceae, Fabaceae (Mimosoideae), Malpighiaceae). According to Wittmann et al. (2004) that greater diversity may indicate a higher level of development of forest, mainly represented by the increase of Cecropia, added to a possible decrease of moisture in relation to previous period. Associated with components of the forest there was also an increase in taxa of floodplain forest and marsh, peaking at 450 years cal BP, which confirms this supposed reduction of humidity. It is possible that the water level of the Javaés River descended due to a more prolonged dry season and so it seasonally lost its connection to the lake, and then, the adjacent soils became flooded for a shorter period of time.

During this period there was also an increase of savanna taxa (peak at about 377 years cal BP). One can assume that the lake margin may have been colonized mainly by Poaceae and Cyperaceae, since these families have aquatic species and it cannot possible to differentiate aquatic plants pollen from others by pollen data (Marchant $e t$ al. 2002). Concomitant to this increase in savanna taxa, there was a huge increase of algae from 596 years cal BP, with its greatest peak at 377 years cal BP. Once Pediastrum (main representative of algae group) is a genus of algae typical of freshwater lakes with a planktonic habit (Pasztaleniec and Poniewozik 2004), its increased occurrence also suggests a loss of connection between the Javaés River and the sampled lake. Thus, the environment that was lotic (flowing water) because the Javaés River connects the lake during the floods possibly became lentic (still water), indicating a reducing rainfall conditions or shortening of the rainy season. However, the lake possibly had yet high water level being favorable for installation and proliferation of this algae type.

From 304 years cal BP until present (Phase BAN III) the hegemony of the forest over other formations remained.
The savanna taxa remained stable in this period with proportions similar to the earlier period confirming the preeminence of the forest $t a x a$, which in this phase showed an alternation of components, being the most representative the Cecropia genus. However, other types were also represented such as Moraceae/Urticaceae, Myrtaceae, Alchornea, Melastomataceae/Combretaceae, Fabaceae (Papilonoideae), Piper, Euphorbiaceae, Apocynaceae, Sapindaceae, Celtis, Fabaceae (Caesalpinioideae), Sapium and Malpighiaceae. This is the phase that has the highest forest taxa diversity, which may indicate a forest on a level of secondary succession, since it does not have a single dominant taxon. At the end of this phase (at about 84 years cal BP) there was an increase of Piranhea, genus typical of Amazonian floodplain forests (Wittmann et al. 2004), suggesting a slight increase in moisture or a longer period of flooded soils due to a rainy season slightly more prolonged. Algae presence diminished if compared to previous phase, but it still had high frequency, indicating an environment marked by lacustrine conditions, like the one of the earlier period.

Palm trees continued to occur at low percentages, indicating there was not occurrence of palm swamps in the study area, inferring from the low representation of Mauritia, although the palm swamp is a typical of Cerrado formation (Ribeiro and Walter 2008). The low representation of Attalea and the absence of charcoal particles suggest that the site was probably not disturbed anthropically. This lack of carbonized particles throughout the core indicates that this local was not human influenced by burning during the last millennium.

\section{Comparison with current regional vegetation}

Correlating the vegetation represented in the core with the current vegetation of the studied area is a difficult task because data on the floristic composition of Bananal Basin region are scarce. However, a study carried out by Santos and Lolis (2007) in the municipality of Pium, near Bananal Island, Brito (2005) and Martins et al. (2008), who performed floristic studies in the municipality of Lagoa da Confusão, with a primary focus in floodplain forests, allow sketching some correlations. The papers highlight the abundance of typical families mainly savanna and rainforest, among them, Anacardiaceae, Arecaceae, Bignoniaceae, Clusiaceae, Dilleniaceae, Fabaceae, Malpighiaceae, Malvaceae, Melastomataceae, Meliaceae, Myrtaceae, Rutaceae, Sapindaceae, Urticaceae (Cecropia sp.) (Table 3). In the pollen analysis presented here it was verified the presence of these same families cited by Brito (2005), Santos and Lolis (2007) and Martins et al. (2008), indicating that the vegetation was constituted in the last millennium by the same current savanna components and the Amazon rainforest.

Whereas the species Byrsonima intermedia and Curatella americana are described in other papers as species occurring in areas of savanna (Freitas and Oliveira 2002; Marques et al. 2003; 
Table 3. List of fitossociologic inventary, adapted for Santos and Lolis (2007) and Martins (2008) (adapted from Brito 2005). 1 = Santos and Lolis (2007); $2=$ Martins (2008).

\begin{tabular}{|c|c|}
\hline \multicolumn{2}{|l|}{ ANACARDIACEAE } \\
\hline Astronium fraxinifolium & 1 \\
\hline Myracrodruon urundeuva Allemao & 2 \\
\hline Tapirira obtusa (Benth.) D.J. Mitch. & 2 \\
\hline \multicolumn{2}{|l|}{ ANNONACEAE } \\
\hline Duguetia furfuracea (A. St.-Hil.) Saff. & 2 \\
\hline Duguetia megalocarpa Maas & 2 \\
\hline Guatteria pubens (Mart.) R.E.Fr. det. J.E. Simonis & 2 \\
\hline Xylopia aromatica (Lam.) Mart. & 2 \\
\hline Xylopia sericea A. St.-Hil. & 2 \\
\hline Annonaceae sp & 1 \\
\hline \multicolumn{2}{|l|}{ APOCYNACEAE } \\
\hline Aspidosperma subincanum Mart. & 2 \\
\hline Himatanthus lancifolius (Müll. Arg.) Woodson & 2 \\
\hline \multicolumn{2}{|l|}{ AQUIFOLIACEAE } \\
\hline Ilex affinis Gardner & 2 \\
\hline \multicolumn{2}{|l|}{ ARECACEAE } \\
\hline Astrocaryum vulgare Mart. & 2 \\
\hline Mauritiella armata (Mart.) Burret & 2 \\
\hline Oenocarpus bacaba Mart. & 1 \\
\hline Syagrus cocoides Mart. & 2 \\
\hline \multicolumn{2}{|l|}{ BIGNONIACEAE } \\
\hline Jacaranda brasiliana (Lam.) Pers. & 2 \\
\hline Tabebuia sp & 1 \\
\hline Tabebuia aurea (Silva Manso) Benth. e Hook. f. ex S. Moore & 2 \\
\hline Tabebuia serratifolia (Vahl) G. Nicholson & 2 \\
\hline \multicolumn{2}{|l|}{ BORAGINACEAE } \\
\hline Cordia alliodora (Ruiz e Pav.) Oken & 2 \\
\hline \multicolumn{2}{|l|}{ BURSERACEAE } \\
\hline Protium grandifolium Engl. & 2 \\
\hline Protium heptaphyllum (Aubl.) Marchand & 1,2 \\
\hline \multicolumn{2}{|l|}{ CANNABACEAE } \\
\hline Cannabaceae sp. & 2 \\
\hline \multicolumn{2}{|l|}{ CARYOCARACEAE } \\
\hline Caryocar villosum (Aubl.) Pers. & 2 \\
\hline \multicolumn{2}{|l|}{ CHRYSOBALANACEAE } \\
\hline Hirtella glandulosa Spreng. & 2 \\
\hline Hirtella hebeclada Moric. ex DC. & 1 \\
\hline Hirtella racemosa Lam. & 2 \\
\hline Licania apetala (E. Mey.) Fritsch & 2 \\
\hline Licania sp1 & 1 \\
\hline Licania sp2 & 1 \\
\hline
\end{tabular}

\begin{tabular}{|c|c|}
\hline CLUSIACEAE & \\
\hline Calophyllum brasiliense Cambess. & 2 \\
\hline Clusiaceae sp & 1 \\
\hline DILLENIACEAE & \\
\hline Curatella americana L. & 1,2 \\
\hline EBENACEAE & \\
\hline Diospyros guianensis (Aubl.) Gürke & 2 \\
\hline Diospyros sericea A. DC. & 2 \\
\hline Diospyros hispida A.DC. & 1 \\
\hline ELAEOCARPACEAE & \\
\hline Sloanea garckeana K. Schum. & 2 \\
\hline Sloanea sp & 1 \\
\hline ERYTHROXYLACEAE & \\
\hline Erythroxylum anguifugum Mart. & 2 \\
\hline EUPHORBIACEAE & \\
\hline Euphorbiaceae $s p$ & 1 \\
\hline Mabea occidentalis Benth. & 2 \\
\hline Maprounea guianensis Aubl. & 2 \\
\hline FABACEAE & \\
\hline Acosmium dasycarpum (Vogel) Yakovlev & 2 \\
\hline Copaifera langsdorffii Desf. & 2 \\
\hline Dipteryx alata Vogel & 2 \\
\hline Hymenaea courbaril L. & 2 \\
\hline Hymenaea sp. & 1 \\
\hline Hymenaea stigonocarpa Mart. ex Hayne & 2 \\
\hline Inga $s p$ & 1 \\
\hline Lonchocarpus campestris Mart. ex Benth. & 2 \\
\hline Machaerium opacum Vogel & 2 \\
\hline Plathymenia reticulata Benth. & 2 \\
\hline Poecilanthe parviflora Benth. & 2 \\
\hline Sclerolobium aureum (Tul.) Baill. & 2 \\
\hline Sclerolobium paniculatum var. rubiginosum (Mart. ex Tul.) Benth. & 1,2 \\
\hline Senna spectabilis (DC.) H.S. Irwin e Barneby & 2 \\
\hline Swartzia apetala Raddi & 2 \\
\hline Swartzia macrostachya var. macrostachya R.S. Cowan & 2 \\
\hline ICACINACEAE & \\
\hline Emmotum nitens (Benth.) Miers & 2 \\
\hline LACISTEMATACEAE & \\
\hline Lacistema hasslerianum Chodat & 2 \\
\hline LAMIACEAE & \\
\hline Aegiphila Ihotskiana Cham. & 2 \\
\hline Vitex polygama Cham. & 2 \\
\hline
\end{tabular}


Table 3. (Continuação)

\begin{tabular}{|c|c|c|c|}
\hline LAURACEAE & & OCHNACEAE & \\
\hline Nectandra gardneri Meisn. & 2 & Ouratea castaneifolia (DC.) Engl. & 2 \\
\hline Ocotea aciphylla (Nees) Mez & 2 & OLACACEAE & \\
\hline LECYTHIDACEAE & & Heisteria laxiflora Engl. & 2 \\
\hline Eschweilera ovata (Cambess.) Miers & 2 & ORCHIDACEAE & \\
\hline LOGANIACEAE & & Orchidaceae sp & 1 \\
\hline Antonia ovata Pohl & 1 & PENTAPHYLACACEAE & \\
\hline LYTHRACEAE & & Ternstroemia sp & 1 \\
\hline Lafoensia pacari A. St.-Hil. & 2 & PROTEACEAE & \\
\hline Physocalymma scaberrimum Pohl & 2 & Roupala montana Aubl. & 2 \\
\hline MALPIGHIACEAE & & Proteaceae sp & 1 \\
\hline Byrsonima indorum S. Moore & 2 & RUBIACEAE & \\
\hline Byrsonima intermedia A. Juss. & 2 & Roupala montana Aubl. & 2 \\
\hline Byrsonima sp. & 1,2 & RUTACEAE & \\
\hline MALVACEAE & & Galipea trifoliata Aubl. & 2 \\
\hline Apeiba tibourbou Aubl. & 2 & Pilocarpus sp. & 2 \\
\hline Ceiba sp. & 2 & Zanthoxylum rhoifolium Lam. & 2 \\
\hline Luehea divaricata Mart. & 2 & Zanthoxylum riedelianum Engl. & 2 \\
\hline Luehea grandiflora Mart. & 2 & SAPINDACEAE & \\
\hline MELASTOMATACEAE & & Allophylus edulis (A. St.-Hil., Cambess. e A. Juss.) Radlk. & 2 \\
\hline Bellucia grossularioides (L.) Triana & 2 & Magonia pubescens A.St.-Hil. & 1 \\
\hline Melastomataceae sp & 1 & Matayba elaeagnoides Radlk. & 2 \\
\hline MELIACEAE & & Matayba guianensis Aubl. & 2 \\
\hline Trichilia hirta L. & 2 & SAPOTACEAE & \\
\hline Trichilia lepidota Mart. & 2 & Chrysophylum sp & 1 \\
\hline Trichilia micrantha Benth. & 2 & SIPARUNACEAE & \\
\hline MENISPERMACEAE & & Siparuna glycycarpa (Ducke) S. S. Renner e Hausner & 2 \\
\hline Abuta grandifolia (Mart.) Sandwith & 2 & Siparuna guianensis Aubl. & 1 \\
\hline MONIMIACEAE & & THEACEAE & \\
\hline Monimiaceae sp & 1 & Theaceae $s p$ & 1 \\
\hline MORACEAE & & URTICACEAE & \\
\hline Brosimum sp & 1 & Cecropia pachystachya Trécul & 2 \\
\hline Sorocea guilleminiana Gaudich. & 2 & VOCHYSIACEAE & \\
\hline MYRISTICACEAE & & Callisthene fasciculata Mart. & 2 \\
\hline Virola sebifera Aubl. & 2 & Qualea dichotoma (Mart.) Warm. & 2 \\
\hline MYRSINACEAE & & Qualea grandiflora Mart. & 1,2 \\
\hline Cybianthus gardneri (A. DC.) G. Agostini & 2 & Qualea multiflora Mart. & 2 \\
\hline MYRTACEAE & & Vochysia divergens Pohl & 2 \\
\hline Calycorectes psidiiflorus (0. Berg) Sobral & 2 & Vochysia pyramidalis Mart. & 2 \\
\hline Calyptranthes concinna DC. & 2 & Vochysia rufa Mart. & 2 \\
\hline Eugenia florida DC. & 2 & Vochysia sp & 1 \\
\hline Myrcia fallax (Rich.) DC. & 2 & & \\
\hline Myrcia multiflora (Lam.) DC. & 1 & & \\
\hline Psidium myrsinoides 0. Berg & 1 & & \\
\hline
\end{tabular}


Ribeiro and Walter 2008), Martins et al. (2008) postulated that these species are established in fragments of floodplain forests ("Ipucas") due to seasonal climate (drought and rain). Nevertheless, in this work, Curatella was recorded during intervals of lower moisture and Byrsonima was recorded throughout core showing higher percentages during periods of lower moisture. The Cecropia genus is assumed to be typical of waterlogged soils of riparian forests and swamp (Toniato et al. 1998; Rodrigues and Nave 2000; Marques et al. 2003). In this study we observed the occurrence of Cecropia throughout Bananal 8 core, and some of its peaks followed periods of higher moisture.

It has been observed that the current vegetation is partly comparable with that observed over the last millennium as well as that vegetation has been dominated by forest at the Bananal Island. It seems that during the Holocene, the vegetation of the Amazon rainforest and its climate has remained stable, as described for the Pata Lake at the northwestern extreme of the Amazon forest (Colinvaux et al. 1996).

\section{Bananal Island climate during the last millennium: comparison to others sites}

The dominance of forest taxa occurred throughout the core indicates that the climate remained moist over the recorded period. Nevertheless, alternations between periods of major and minor flooding events were inferred through slight changes in vegetation composition. In a core taken from Pantanal (Mato Grosso State), McGlue et al. (2012) also noticed changes in the detrital granulometry, biogeochemical indicators (such as values of the ratio between carbon and nitrogen indicated by mixed organic material) and changes in the sponge spicules types (lentic or lotic) associated to changes in the water level from the lake, caused by increase of annual precipitation during the Holocene, with increased the seasonal flooding events.

According to Urrego et al. (2006), who worked with floodplain forests in Colombia, the differences in the levels of the river and in the drainage conditions reflected in the vegetational composition, in which an increase of Mauritiella and Campnosperma suggests seasonal flooding with better drainage. The increase of Ilex followed by Oenocarpus is indicative of high flood levels. These authors also reported palm swamp presence, due to the good drainage conditions, a fact that was not verified in the region of Bananal Island because it has been colonized by forest whose environment does not favor the growing of swamp palm, due to both the interspecific competition and high water levels.

In the Central Brazilian Cerrado, in comparison with the Late Pleistocene, the climate during the Late Holocene became semi humid with a prolonged dry season with three to five months of drought, a condition that remains until now (e.g. de Oliveira 1992; Ferraz-Vicentini and SalgadoLabouriau 1996; Barberi et al. 2000). At Lagoa da Confusão, Tocantins, during the Late Holocene the climate was wetter than in the Early Holocene (Behling, 2002). This author found an increase of aquatic plants which he attributed to the expansion of the lake due to a probable increase in rainfall.

The occurrence of wetter climate during the Late Holocene was also observed in the regions of ecotones savanna/forest from Humaitá-AM (Freitas et al. 2001; Pessenda et al. 2001) and in the Roraima State (Meneses et al. 2013). In Humaitá the authors observed an expansion of the forest over the savanna for the last millennium. While in Roraima was verified expansion and contraction cycles of the forest related to fire events. The last cycle 300 years BP was marked by the expansion of the forest due to a wetter climate and reduction of fire events. In summary, all these studies carried out in different regions of savanna and ecotones with Amazon rainforest suggested the dominance of a wetter climate during the last millennium very similar to the current, which was also shown in this study for the Bananal Island.

\section{CONCLUSIONS}

Pollen record obtained from Bananal 8 core, allowed us to infer about the vegetation changes and climate conditions during the last millennium in the Bananal Island, Tocantins State. During the entire last millennium the environment was dominated by forest reflecting a wet climate. However, some changes took place in the vegetation composition driven by increase and/or decrease of rainfall. At the beginning of the record $(920-770 \mathrm{yr}$ cal BP) the wet climate and high rainfall produced flooding during long rainy seasons that maintained the Javaés River connected to studied lake as showed by a homogenous forest dominated by Moraceae/Urticaceae. The following period (770-304 yr cal BP) was marked by reduced rainfall and shortening of the rainy season. This isolated lake from Javaés River for long periods allowing the appearance of a more diverse forest and ultimately components a floodplain forest and marsh vegetation, adapted to waterlogged soils. During this period Poaceae and Cyperaceae settled the lake margins, while the Pediastrum, a genus of Algae colonized the water surface evidencing the lacustrine trait of this environment. Since 304 years cal BP to the present day this environment remained dominated by this diverse forest as in the previous period. The lacustrine conditions also were similar with a slight increase of moisture in the last 84 years as indicated by increase of Piranhea. Nowadays, the Bananal Island is an important region of ecotone between two important biomes where the vegetational and environmental changes can be more easily observed and studied. 


\section{ACKNOWLEDGMENTS}

The author thanks the team from Palynology's Laboratory from Universidade Federal do Rio de Janeiro, and financial support from Conselho Nacional de Desenvolvimento Científico e Tecnológico (CNPq), Process nº: 483980/2010-2, Edital MCT/CNPq 14/2010 - Universal. This paper is part of the Master's dissertation of the first author, with grants from Coordenação de Aperfeiçoamento de Pessoal de Nível Superior (CAPES).

\section{REFERENCES}

Absy, M.L.; Cleef, A.L.M.; Fournier, M.; Martin, L.; Servant, M.; Sifeddine, A.; et al. 1991. Mise en évidence de quatre phase d'ouverture de la forêt dense dans le sud-est de l'Amazonie au cours des 60000 dernières années. Premiére comparaison avec d'autres régions tropicales. C.R. Académie Science Paris, 312: 673-678.

Barberi, M.; Salgado-Labouriau, M.L.; Suguio, K. 2000. Paleovegetation and paleoclimate of "Vereda de Águas Emendadas", DF, Central Brazil. Journal South American Earth Sciences, 13: 241-254, DOI: 10.1016/S0895-9811.

Barberi, M. 2001. Mudanças paleoambientais na regiāo dos cerrados do Planalto Central durante o Quaternário Tardio: o estudo da lagoa Bonita. DF. Tese de doutorado, Universidade de São Paulo. 210p.

Behling, H. 2002. Late Quatenary vegetation and climate dynamics in southeastern Amazonia inferred from lagoa da Confusão in Tocantins State, noerthern Brazil. Amazoniana, 17: 27-39.

Borma, L.S.; Rocha, H.R.; Cabral, O.M.; Von Randow, C.; Collicchio, E.; Kurzatkowski, D.; et al. 2009. Atmosphere and hydrological controls of the evapotranspiration over a floodplain forest in the Bananal Island region, Amazonia. Journal of Geophysical Research, 114: G01003, DOI: 10.1029/2007JG000641.

Brasil. 1981. Instituto Brasileiro de Desenvolvimento Florestal IBDF, Fundação Brasileira para a Conservação da Natureza. Ministério do Meio Ambiente. Plano de Manejo: Parque Nacional do Araguaia. Brasília, 103p.

Brito, E.R. 2005. Floristica e estrutura de fragmentos naturais de florestas inundáveis Ipucas e identificação de áreas degradadas da fazenda Lago Verde, Lagoa da Confusão-TO. Tese de Doutorado, Universidade Federal de Viçosa, Viçosa, Minas Gerais. 80p.

Bush, M.B.; De Oliveira, P.E.; Colinvaux, P.A.; Miller, M.C.; Moreno, J.E. 2004. Amazonian paleoecological histories: one hill, three watersheds. Palaeogeography, Palaeoclimatology, Palaeoecology, 214: 359-393, DOI: 10.1016/j.palaeo.2004.07.031.

Carreira, L.M.M.; Barth, O.M. 2003. Atlas de Pólen da vegetação de Canga da Serra de Carajás. Museu Paraense Emílio Goeldi. Pará-Brasil, 112p.

Colinvaux, P.; De Oliveira, P.E.; Patiño, J.E.M. 2005. Manual e Atlas Palinológico da Amazônia. Taylor \& Francis e-Library, 97p.

Colinvaux, P.A.; De Oliveira, P.E.; Moreno, J.E.; Miller, M.C.; Bush, M.B. 1996. A long pollen record from lowland Amazonia: forest and cooling in glacial times. Science, 247: 85-88, DOI:10.1126/ science.274.5284.85.
De Oliveira, P.E. 1992. A palynological record of Late Quaternary vegetational and climatic change in Southeastern Brazil. Doctor degree thesis, Ohio State University, 242p.

Devi, M.K. 2012. Ecotourism in assam: A promising opportunity for development. South Asian Journal of Tourism and Heritage, 5: 1, DOI: 10.1016/j-annals.2008.01.002.

Dias, C.M.; Pastore, D.H.; Borma, L.S.; Bevilacqua, L. 2011. Modelling and numerical simulation of the velocity field in the Parque Estadual do Cantão (TO), Brazil. Mathematical and Computer Modelling, 53: 1575-1581, DOI: 10.1016/j. $\mathrm{mcm} .2010 .06 .021$.

Eiten, G. 1985. Vegetation near Santa Teresinha, NE Mato Grosso. Acta Amazonica, 15: 275-301.

Erdtman, G. 1952. Pollen Morphology and Plant Taxonomy. Angiosperms. An Introduction to Palynology. Almqvist and Wiksell, Stockholm, 1952, 539p.

Faegri, K.; Iversen, J. 1989. Textbook of Pollen Analysis. Wiley, Chichester, United Kingdom, 1989, 328p.

Ferraz-Vicentini, K.R.; Salgado-Labouriau, M.L. 1996. Palynological analysis of a palm swamp in central Brazil. Journal of South American Earth Science, 9: 207-219, DOI: 10.1016/08959811(96)00007-7.

Ferraz-Vicentini, K.R. 1999. História do fogo no Cerrado: uma análise palinológica. Tese de doutorado, Instituto de Ciências Biológicas, Universidade de Brasília, Brasília, Distrito Federal. 208p.

Freitas, C.V.; Oliveira, P.E. 2002. Biologia reprodutiva de Copaifera langsdorffi Desf. (Leguminosae, Caesalpinioideae). Revista Brasileira de Botânica, 25: 311-321, DOI: S010084042002000300007.

Freitas, H.A.; Pessenda, L.C.R.; Aravena, R.; Gouveia, S.E.M.; De Souza Ribeiro, A.; Boulet, R. 2001. Late Quaternary vegetation dynamics in the southern Amazon Basin inferred from carbon isotopes in soil organic matter. Quaternary Research, 55: 39-46, DOI: $10.1006 /$ qres.2000.2192.

Grimm, E.C. 1987. Coniss: A Fortran 77 program for stratigraphically constrained cluster analysis by the method of the incremental sum of squares. Computers and Geosciences, 13: 13-35, DOI: 10.1016/0098-3004(87)90022-7.

Hermanowski, B.; Costa, M.L.; Carvalho, A.T.; Behling, H. 2012. Palaeoenvironmental dynamics and underlying climatic changes in southeast Amazonia (Serra Sul dos Carajás, Brazil) during the late Pleistocene and Holocene. Palaeogeography, Palaeoclimatology, Palaeoecology, 365-366: 227-246, DOI: 10.1016/j.palaeo.2012.09.030.

Irion, G.; Bus, M.B.; Nunes De Mello, J.A.; Stüben, D.; Neumann, T.; Müller, G.; et al. 2006. A multiproxy palaeoecological record of Holocene lake sediments from the Rio Tapajós eastern Amazonia. Palaeogeography, Palaeoclimatology, Palaeoecology, 240: 523-535, DOI: 10.1016/j.palaeo.2006.03.005.

Marchant, R.; Almeida, L.; Behling, H.; Berrio, J.C.; Bush, M.; Cleef, A.; et al. 2002. Distribution and ecology of parent taxa of pollen lodged within the Latin American Pollen Database. Review of Palaeobotany and Palynology, 121: 1-75, DOI: 10.1016/ S0034-6667(02)00082-9. 
Marques, M.C.M.; Silva, S.M.; Salino, A. 2003. Florística e estrutura do componente arbustivo-arbóreo de uma floresta higrófila da bacia do rio Jacaré-Pepira, SP, Brasil. Acta Botanica Brasilica, 17: 495-506, DOI: 10.1590/S0102-33062003000400002.

Martins, F.Q.; Batalha, M.A. 2006. Pollination systems and floral traits in cerrado woody species of the Upper Taquari region (central Brazil). Brazilian Journal of Biology, 66: 543-552, DOI: 10.1590/S1519-69842006000300021.

Martins, S.V.; Brito, E.R.; Filho, A.T.O.; Silva, F.; Silva, E. 2008. Floristic composition of two wetland forests in Araguaian Plain, State of Tocantins, Brazil, and comparison with other areas. Revista Árvore, 32: 129-141, DOI: 10.1590/S010067622008000100015.

McGlue, M.M.; Silva, A.; Zani, H.; Corradini, F.A.; Parolin, M.; Abel, E.J.; et al. 2012. Lacustrine records of Holocene flood pulse dynamics in the upper Paraguay River watershed (Pantanal wetlands, Brazil). Quaternary Research, 78: 285-294, DOI: 10.1016/j.yqres.2012.05.015.

Meneses, M.E.N.S.; Costa, M.L.; Behling, H. 2013. Late Holocene vegetation and fire dynamics from a savanna-forest ecotone in Roraima state, northern Brazilian Amazon. Journal of South American Earth Sciences, 42: 17-26, DOI: 10.1016/j. jsames.2012.10.007.

Mileski, E. 1994. Aspecto da vegetação e do ecossistema da Ilha do Bananal. Mapa fitoecológico e indicadores da pressão antrópica. Gráfica da Secretária de Assuntos Estratégicos, Brasília, Distrito Federal, 1994, 104p.

Mittermeier, R.A.; Myers, N.; Thomsen, J.B.; Fonseca, G.A.B.; Olivieri, S. 1998. Biodiversity hotspots and major tropical wilderness areas: approaches to setting conservation priorities. Conservation Biology, 12: 516-520, DOI: 10.1046/j.15231739.1998.012003516.x.

Myers, N.; Mittermeier, R.A.; Mittermeier, C.G.; Fonseca, G.A.B.; Kent, J. 2000. Biodiversity hotspots for conservation priorities. Nature, 403: 853-858, DOI: 10.1046/j.15231739.1998.012003516.x.

Nunes, G.M.; Souza Filho, C.R.; Ferreira, L.G. 2012. Discriminação de fitofisionomias na Amazônia central por meio de índices de vegetação de imagens com resolução espacial moderada. Revista Geografica Acadêmica, 6: 05-14.

Odum, E.P. 1976. Fundamentos da ecologia. (Fundamentals of ecology, 1953). Baeta Neves, C.M. (Trad.). 2 ed. Lisboa: Fundação Calouste Gulbenkian, 1976, 595p.

Parizzi, M.G.; Salgado-Labouriau, M.L.; Koehler, C. 1998. Genesis and environmental history of lagoa Santa, SE Brazil. The Holocene, 8: 311-321, DOI: 10.1191/095968398670195708.

Pasztaleniec, A.; Poniewozik, M. 2004. Pediastrum species (Hydrodictyaceae, Sphaeropleales) in phytoplankton of Sumin Lake (Łęczna-Włodawa Lakeland). Acta Societatis Botanicorum Poloniae, 73: 39-46, DOI: 10.5586/asbp.2004.006.

Pessenda, L.C.R.; Boulet, R.; Aravena, R.; Rosolen, V; Gouveia, S.E.M.; Ribeiro, A.S.; et al. 2001. Origin and dynamics of soil organic matter and vegetation changes during the Holocene in a forest-savanna transition zone, Brazilian Amazon region. The Holocene, 11: 250-254, DOI: 10.1191/095968301668898509.
Raven, P.H.; Evert, R.F.; Eichhorn, S.E. 2007. Biologia Vegetal, $7^{\mathrm{a}}$. ed. Coord. Trad. J.E. Kraus. Editora Guanabara Koogan, Rio de Janeiro, 2007, 906p.

Ribeiro, J.F.; Walter, B.M.T. 2008. As principais fitofisionomias do cerrado. In: Sano, S. M; Almeida, S. P; Ribeiro, J. F. (Ed.) Cerrado: Ecologia e Flora. v.1. Embrapa Cerrados, Embrapa Informação Tecnológica, Brasília, Distrito Federal, p.151-212.

Rivas, S. 1978. Polen y Esporas (Introduccion a La Palinologia y Vocabulário Palinologico). H. Blume Ediciones. Madrid, Espanha, 1978, 211p.

Rodrigues, R.R.; Nave, A.A. 2000. Heterogeneidade florística das matas ciliares. In: Rodrigues, R.R.; Leitão-Filho, H.F. (Eds.) Matas ciliares: conservação e recuperação. São Paulo: Edusp/ Fapesp, p.45-71.

Rossetti, D.F.; Bertani, T.C.; Zani, H.; Cremon, E.H.; Hayakawa, E.H. 2012. Late Quaternary sedimentary dynamics in Western Amazonia: Implications for the origin of open vegetation/forest contrasts. Geomorphology, 177-178: 74-92, DOI: 10.1016/j. geomorph.2012.07.015.

Roubik, D.W.; Moreno, J.E. 1991. Pollen and spores of Barro Colorado Island. Monographs in Systematic Botany. Missouri Botanical Garden, St Louis, MO, 1991, 270p.

Salgado-Labouriau, M.L.; Casseti, V.; Ferraz-Vicentini, K.R.; Martin, L.; Soubiès, F.; Suguio, K.; et al. 1997. Late Quaternary vegetational and climatic changes in cerrado and palm swamp from Central Brazil. Palaeogeography, Palaeoclimatology, Palaeoecology, 128: 215-226, DOI: 10.1016/S0031-0182(96)00018-1.

Salgado-Labouriau, M.L. 1973. Contribuição à Palinologia dos Cerrados. Editora Academia Brasileira de Ciências. Rio de Janeiro, 1973, 291p.

Santos, E.R.; Lolis, S.F. 2007. Análise florística em comunidades florestais nos municípios de Caseara, Marianópolis e Pium, no estado do Tocantins. Revista Carbono Social, 01: 24-31.

SEPLAN/TO. 2008. Atlas do Tocantins: subsidios ao planejamento da gestão territorial. Secretaria do Planejamento e Meio Ambiente, Diretoria de Zoneamento Ecológico-Econômico-DZEE. 5a. ed. Secretaria de Planejamento, Palmas, Tocantins, 2008, 69p.

Stuiver, M.; Reimer, P. 1993. Extended ${ }^{14} \mathrm{C}$ database and revised CALIB radiocarbon calibration program. Radiocarbon, 35: 215-230.

Toniato, M.T.Z.; Leitão Filho, H.F.; Rodrigues, R.R. 1998. Fitossociologia de um remanescente de floresta higrófila (mata de brejo) em Campinas, SP. Revista Brasileira de Botânica, 21: 197-210, DOI: 10.1590/S0100-84041998000200012.

Urrego, L.E.; Molina, L.A.; Urrego, D.H.; Ramírez, L.F. 2006. Holocene space-time succession of the middle Atrato wetlands, Chocó biogeographic region, Colombia. Palaeogeography, Palaeoclimatology, Palaeoecology, 234: 45-61, DOI: 10.1016/j. palaeo.2005.10.018.

Valente, C.R.; Latrubesse, E.M.; Ferreira, L.G. 2013. Relationships among vegetation, geomorphology and hydrology in the Bananal Island tropical wetlands, Araguaia River basin, Central Brazil. Journal of South American Earth Sciences, 30: 1-11, DOI: 10.1016/j.jsames.2012.12.003. 
Valente, C.R. 2007. Controles físicos na evoluçâo das unidades geoambientais da Bacia do Rio Araguaia, Brasil Central. Tese de Doutorado, Universidade Federal de Goiás, Goiânia, Goiás. 163p.

Wittmann, F.; Junk, W.J.; Piedade, M.T.F. 2004. The várzea forests in Amazonia: flooding and the highly dynamic geomorphology interact with natural forest succession. Forest Ecology and Management, 196: 199-212, DOI: 10.1016/j. foreco.2004.02.060

Recebido em 02/06/2014

Aceito em 29/09/2014 
